\title{
MUTATIONS IN PULMONARY ADENOCARCINOIMA. FREQUENCY STUDY FROIM A ONCOLOGY CENTRE IN CENTRAL KERALA.
}

KEY WORDS: EGFR, ALK, ROS, LUNG ADENOCARCINOMA, MUTATION

\section{Aniya Antony}

Vanesa John T*

Sandhra Usman

\section{Joy Augustine}

Assistant Professor, Department Of Pathology , Amala Institute Of Medical Sciences , amala Nagar, Thrissur, Kerala.

Assistant Professor, Department Of Pathology, Jubilee Mission Medical College And Research Institute, Thrissur, Kerala. * Corresponding Author

Senior Resident, Department Of Pathology, Mes Academy Of Medical Sciences, Palachode, Perinthalmanna, Kerala.

Professor \&head Of Department, Department Of Pathology, Amala Institute Of Medical Sciences, Amala Nagar, Thrissur, Kerala.

Background: Non small cell carcinomas of lung, notably adenocarcinoma is associated with genetic mutations in EGFR (chromosome 7) , ALK (chromosome 2), ROSl(chromosome 6). The patients harbouring these mutations are greatly benefited from tyrosine kinase inhibitor targeted chemotherapy. The prevalence of these mutations in central kerala has not been studied and documented.

E Aim: This study aims to analyse the frequency of different mutations in lung adenocarcinomas presenting to a oncology centre in kerala.

Study Design: Descriptive study.

Materials And Methods: The study spanned over a period of two years from 2019-2021. A total of 169 consecutive lung adenocarcinomas were studied.

PCR for EGFR was done in 89 cases and were tested for the common mutations. ALK1 IHC using ALK-D5F3 clone and ROS with ROS-D4D 6 clones were done in 40 cases.

Results: EGFR mutation was present in 15 cases (17.44\%). The most common age range was 40-60yrs. Two most common patterns were solid and acinar. ALK and ROS 1 mutation was found in 3 cases (7.5\%) and 2 cases ( $5 \%$ ) respectively. 4 cases (16.66\%) of EGFR mutant lung adenocarcinoma patients had metastasis.

\section{INTRODUCTION}

Lung cancer is considered to be one of the leading causes of cancer-related deaths worldwide with more than 1 million cases diagnosed every year ${ }^{1}$.

Non small-cell lung cancer (NSCLC) includes 3 major cell types (adenocarcinoma, squamous cell carcinoma and large cell carcinoma), and these can be further divided into various subtypes or variants. NSCLC accounts for most $(\sim 85 \%)$ of the lung cancers, with lung adenocarcinoma being the most common subtype ${ }^{1,2}$.

Major advances in understanding the pathogenesis of NSCLCs, have led to the identification of molecular pathways, which promotes tumor growth. One among them, is the discovery of epidermal growth factor receptor (EGFR). EGFR is a transmembrane receptor tyrosine kinase protein that is expressed in most of the normal epithelial, mesenchymal, and neural tissue. Mutations in EGFR has shown increased downstream signalling. Thereby promoting cell proliferation, differentiation and growth ${ }^{3,4}$.EGFR TKI targeted therapies have significantly changed the outlook on this subset of patients. $^{5}$

EGFR mutations are commonly detected in adenocarcinomas. $90 \%$ of mutations have been deletions noted in exon $19^{3,4}$. When these EGFR mutated patients are treated with tyrosine kinase inhibitors like gefitinib and erlotininb, nearly all respond compared to patients without mutation. This mutation has not been demonstrated in smokers ${ }^{6}$.

Anaplastic lymphoma kinase (ALK) and c-ros oncogene 1 (ROS1) are the other mutations frequently found in NSCLC. Frequency of $A \mathrm{LK}$ rearrangement in earlier studies is around 3-7\% of NSCLC ${ }^{1,7}$ and ROS 1 being approximately around 1$2 \%$ of NSCLC ${ }^{7,8}$. Identifying the above mutations are very important as these patients are likely to benefit from targeted therapy. Those who are positive for ROSl mutations are treated with crizotinib ${ }^{8}$.

www.worldwidejournals.com

\section{MATERIALS AND METHODS}

Lung biopsies of 169 patients were retrieved from the archives of the department of pathology, at Amala institute of medical sciences, Thrissur from January 2019 to January 2021.

\section{Study Inclusion Criteria}

- Lung biopsies

- Biopsies from metastatic sites such as lymph nodes, bone, pleura etc. Which were proved to be of pulmonary origin by IHC markers.

\section{Study Exclusion Criteria}

- Primary Lung carcinomas other than adenocarcinoma.

- Carcinoma / sarcoma metastasis to lung from other sites.

- Cases where slides and paraffin blocks were not available for review.

\section{Histological Examination}

All specimens are fixed in 10\% neutral buffered formalin, embedded in paraffin, and stained with H\&E. The sections were classified according to the 2015 WHO Classification of lung tumors by experienced pathologists. We also graded the tumors into well differentiated ( $>95 \%$ glands), moderately differentiated (50-95\% glands) and poorly differentiated (< $50 \%$ glands) depending on the extent of glandular differentiation using the system in endometrial cancers ${ }^{1}$. IHC for lung adenocarcinoma panel was done in 25 cases to aid the H\&E examination.

\section{Reagents And Equipments}

Immunochemistry with $\mathrm{p} 40, \mathrm{TTF} 1$,Napsin A was performed on unstained tissue sections of 4 microns each using poly-Llysine coated slides on automated immunostainer( Ventana Benchmark GX).

\section{PCR For Epidermal Growth Factor Receptor Mutation} Detection

PCR for EGFR was done in 89 confirmed adenocarcinoma cases. Paraffin embedded tissue blocks were sent for 
mutation analysis. Tissues were tested for the common mutations described in lung cancer for example exons 19 , exon 20 and exon 21 . The remaining cases it was not done due to insufficient tissue not available for testing.

\section{Immunohistochemistry For ALK \& ROS}

IHC was performed for 40 cases of adenocarcinoma to detect expression of ALK and ROS. This was outsourced to a NABL accredited laboratory (MedGenome). Clones used were ALK-D5F3 (Ventana) and ROS-D4D6 (cell signalling technology).

\section{RESULTS}

Epidermal Growth Factor Receptor Mutation. (Tablel)

A total of 86 cases were studied for EGFR mutation.

In our study incidence of EGFR mutation, was noted in 15 patients (17.44\%). Amongst those with the mutation, females showed slight preponderance than males . Majority of the positive cases were noted in the age group between 40-60, which were $9(60 \%)$ and $6(40 \%)$ of them were above 60 years.

Correlating Histoloigical Grade And Patterns With Epidermal Growth Factor Receptor Mutation.(table 1)

In our study, 8 cases (53.3\%) were histological grade II, 6 $(40 \%)$ with grade III histology and 1 case showed grade I histology.

In EGFR positive cases, acinar being the most frequent pattern in 8 cases $(53.3 \%)$ followed by solid in 4 cases(26.6\%), lepidic in 2 cases (13.3\%) and 1 case with papillary pattern $(6.6 \%)$.

Among the different mutation analysis performed, our study group showed Exon 19 deletions to be the most frequent which was found in $10 / 15$ cases $(66.6 \%)$ followed by exon 21 mutation in $3 / 15$ cases $(20 \%)$ and 2 cases $(13.3 \%)$ showed exon 20 deletions.

Table 1.Frequency Of EGFR Mutation

\begin{tabular}{|c|c|c|}
\hline & \multicolumn{2}{|c|}{$\begin{array}{l}\text { EGFR PCR for Exon 19/exon 20/ } \\
\text { exon } 21\end{array}$} \\
\hline & Positive (\%) & Negative(\%) \\
\hline Frequency & $15(17.44)$ & $71(82.5)$ \\
\hline $\begin{array}{l}\text { Gender } \\
\text { Male } \\
\text { Female } \\
\end{array}$ & $\begin{array}{l}7(46.6) \\
8(53.3)\end{array}$ & $\begin{array}{l}48(67.6) \\
24(33.8)\end{array}$ \\
\hline $\begin{array}{l}\text { Age } \\
<40 \\
40-60 \\
>60\end{array}$ & $\begin{array}{l}0 \\
9(60) \\
6(40)\end{array}$ & $\begin{array}{l}2(2.8) \\
26(36.6) \\
44(61.97)\end{array}$ \\
\hline $\begin{array}{l}\text { Grade } \\
\text { WD I } \\
\text { MD II } \\
\text { PD III } \\
\end{array}$ & $\begin{array}{ll}1 & (6.6) \\
8 & (53.3) \\
6 & (40)\end{array}$ & \begin{tabular}{|l}
$6(8.4)$ \\
$41(57.7)$ \\
$24(33.8)$
\end{tabular} \\
\hline $\begin{array}{l}\text { Patterns } \\
\text { Lepidic } \\
\text { Acinar } \\
\text { Mixed } \\
\text { Papillary } \\
\text { Solid } \\
\text { Mucinous/signet } \\
\text { ring } \\
\text { Micropapillary }\end{array}$ & $\begin{array}{l}2(13.3) \\
8(53.3) \\
0 \\
1(6.6) \\
4(26.6) \\
0 \\
0\end{array}$ & $\begin{array}{l}6(8.4) \\
39(54.9) \\
0 \\
2(2.8) \\
22(30.9) \\
\\
1(1.4) \\
1(1.4)\end{array}$ \\
\hline
\end{tabular}

\section{ALK and ROS}

ALK and ROS immunohistochemistry was performed in 40 cases of adenocarcinoma. 3 out of 40 cases showed ALK positivity and 2 out of 40 cases showed ROS 1 positivity. One case showed equivocal staining for ROSI IHC. The rest of the cases were negative.

\section{DISCUSSION}

In this two year study of EGFR, ALK, ROSl mutations in lung adenocarcinoma, conducted in our institute showed a predominance of females. This is in concordance with other similar studies ${ }^{4,5,9,10}$.(Table 2). EGFR Mutation was more frequently noted in the age group of 40-60 years. The study by Matsumura $\mathrm{M}$ et al ${ }^{11}$ and $\mathrm{Ho} \mathrm{HL}$ et al ${ }^{12}$ showed a higher median age of 70 yrs than any other study conducted on lung carcinoma. The reason could be attributed to the higher life span of Japanese population.

Table 2. Comparison Of Results Of Epidermal Growth Factor Receptor Mutation In The Present Study With Similar Studies

\begin{tabular}{|l|l|l|l|l|l|}
\hline Study & $\begin{array}{l}\text { Frequency in } \\
\text { lung } \\
\text { adenocarcino } \\
\text { mas (\%) }\end{array}$ & $\begin{array}{l}\text { Age } \\
\text { range }\end{array}$ & $\begin{array}{l}\text { Median } \\
\text { age of } \\
\text { patients } \\
\text { (yrs) }\end{array}$ & $\begin{array}{l}\text { Males } \\
\text { (\%) }\end{array}$ & $\begin{array}{l}\text { Females } \\
\text { (\%) }\end{array}$ \\
\hline $\begin{array}{l}\text { Present } \\
\text { study } \\
\text { (n=86) }\end{array}$ & 17.44 & $30-77$ & 50 & 46.6 & 53.3 \\
\hline $\begin{array}{l}\text { Arafat } \\
\text { Tfayli et } \\
\text { al } \\
\text { (n=205) }\end{array}$ & 15.6 & NA & 63.4 & 8.8 & 29 \\
\hline $\begin{array}{l}\text { Hee- } \\
\text { Young } \\
\text { Yoon et } \\
\text { al } \\
\text { (n=1020) }\end{array}$ & 38.0 & NA & 66 & 39.7 & 60.3 \\
\hline $\begin{array}{l}\text { J.Matthe } \\
\text { w et al } \\
\text { (n=121) }\end{array}$ & 19 & NA & NA & NA & NA \\
\hline
\end{tabular}

Among the different Non small cell lung carcinomas (NSCLC), adenocarcinoma is most commonly tested for EGFR mutation status ${ }^{9}$. Bronchioalveolar carcinoma (BAC), which is a subtype of adenocarcinoma is frequently associated with EGFR mutation than other types of adenocarcinoma ${ }^{9}$.

In the present study the well differentiated adenocarcinoma (6\%) showed the least frequency of expression of EGFR. While the moderately differentiated adenocarcinoma showed the highest EGFR expression (53.3\%). Poorly differentiated adenocarcinoma showed $40 \%$ expression.

Of the 86 samples tested for EGFR mutation, 15 cases had mutation (17.44\%). Amongst them, the predominant histological pattern in our study is acinar $(53.3 \%)$, followed by solid $(26.6 \%)$, lepidic (13.3\%) and papillary $(6.6 \%)$. This is in concordance with the study by Gupta Pet al ${ }^{1}$. (Figure 1-4)

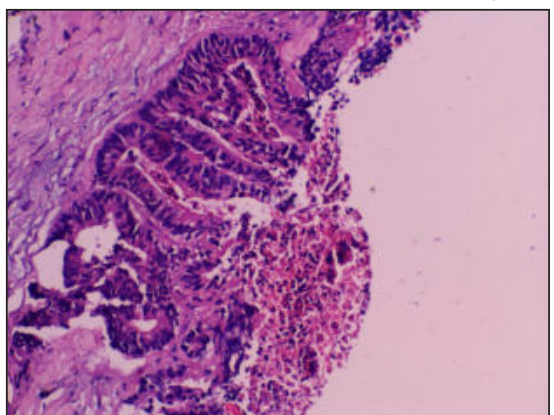

Figure 1: Glandular pattern ; H\&E-100X

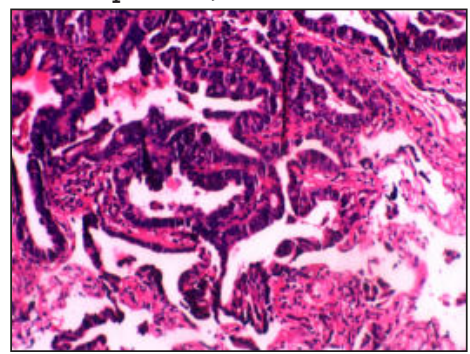

Figure 2: Papillary pattern;H \& E-200X 


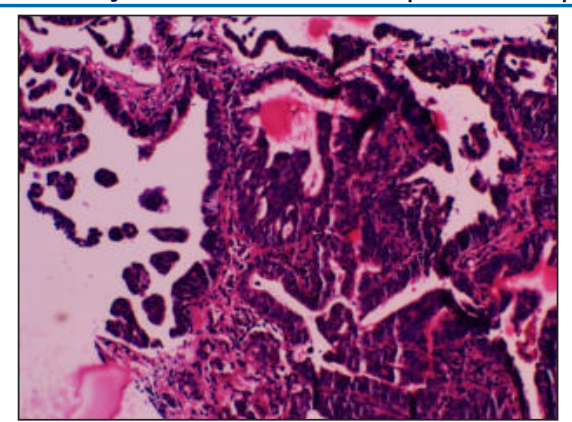

Figure 3: Micropapillary pattern; H\&E- 100X

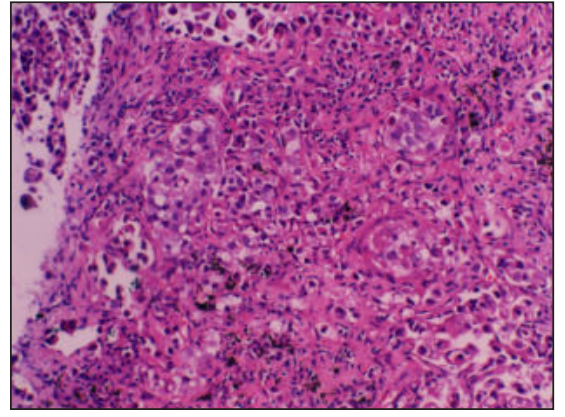

Figure 4: Solid pattern; H\&E- 400X

The major mutations analysed were deletions in exon $18,19,20,21$. The commonest being Exon 19 deletions for most mutant positive patients $(66.6 \%)$ followed by exon 21 mutation $(20 \%)$ and 2 cases by exon 20 . This was similar to other studies by Tfayli $\mathrm{A}$ et al ${ }^{10}$, Ho HL et al ${ }^{12}$ and Reinersman JMet al. ${ }^{6}$

The EGFR mutant lung adenocarcinomas have a better survival than the wild type, when treated with Tyrosine kinase inhibitors ${ }^{4,12}$. While the same study also demonstrated good prognosis in patients with El9 deletion and adverse outcomes in patients with $\mathrm{E} 21$ mutation.

\section{Anaplastic Lymphoma Kinase}

The frequency of $A L K$ expression is $7.5 \%$ in our study. Song $Z$ et al ${ }^{7}$ in his study found the incidence of $A L K$ to be $12.2 \%$.(Table 3-4).

\section{ROS1}

The frequency of ROSl is $5 \%$ in our study which is higher than the study by Bergethon $\mathrm{K}$ et al ${ }^{13}$ in young never smokers .(Table 3-4).The crizotinib chemotherapy which is targeted against ALK and ROSl mutation is beneficial for the young patients.

Table 3. Frequency Of ALK And ROS1 Mutation In Lung Adenocarcinoma.

\begin{tabular}{|l|l|l|l|}
\hline IHC & $\begin{array}{l}\text { SAMPLES } \\
\text { TESTED }\end{array}$ & $\begin{array}{l}\text { SAMPLES } \\
\text { POSITIVE }\end{array}$ & $\begin{array}{l}\text { Prevalence in } \\
\text { present study }\end{array}$ \\
\hline $\begin{array}{l}\text { ALK IHC } \\
\text { D5F3 } \\
\text { CLONE }\end{array}$ & 40 & 3 & $7.5 \%$ \\
\hline $\begin{array}{l}\text { ROS1 IHC } \\
\text { D4D6 } \\
\text { CLONE }\end{array}$ & 40 & 2 & $5 \%$ \\
\hline
\end{tabular}

Table 4. Comparison Of Frequency Of ALK And ROS 1 Mutations.

\begin{tabular}{|l|l|l|l|}
\hline Test & $\begin{array}{l}\text { Present study } \\
(\mathbf{n = 4 0 )}\end{array}$ & $\begin{array}{l}\text { Arafat Tfayli } \\
\text { et al (n=205) }\end{array}$ & $\begin{array}{l}\text { Z song et al } \\
(\mathbf{n = 7 3 2})\end{array}$ \\
\hline $\begin{array}{l}\text { ALK IHC } \\
\text { D5F3 CLONE }\end{array}$ & $7.5 \%$ & $1.9 \%$ & $12.2 \%$ \\
\hline $\begin{array}{l}\text { ROS1 IHC } \\
\text { D4D6 CLONE }\end{array}$ & $5 \%$ & Not studied & $4.4 \%$ \\
\hline
\end{tabular}

\section{Other Findings}

Among our patients of lung adenocarcinoma, 24 had metatstatic disease, either distant or nodal metastases. Distant metatstatic sites were to the bone, brain etc.

Out of total of 24 cases which had metastases, 4 tested positive for EGFR mutation (16.66\%) and one positive for ALK mutation which again emphasizes the importance of targeted chemotherapy.

\section{CONCLUSION}

The study conducted in lung adenocarcinoma, in our cancer research institute represents an overall picture of EGFR, ALK, ROS mutation testing, in a tertiary centre in Kerala.

Choosing to test for mutation will increase the proportion of the patients who get benefitted from specific therapy. In conclusion, the discovery of many theranostic molecular biomarkers in NSCLC has greatly changed the classification of lung cancer, and thus its management.

\section{REFERENCES}

1. Gupta P, Gowrishankar S, Swain M. Epidermal growth factor receptor and anaplastic lymphoma kinase mutation in adenocarcinoma lung: Their incidence and correlation with histologic patterns. Indian J Pathol Microbiol 2019;62(1):24-30

2. Dearden S, Stevens J, Wu YL, Blowers D. Mutation incidence and coincidence in non small-cell lung cancer: meta-analyses by ethnicity and histology (mutMap).Ann Oncol 2013;24(9):2371-6.

3. Bethune G, Bethune D, Ridgway N, Xu Z. Epidermal growth factor receptor (EGFR) in lung cancer: an overview and update.JThorac Dis 2010;2(1):48-51.

4. Yoon HY, Ryu JS, Sim YS, Kim D, Lee SY, Choi J, Park S, Ryu YJ, Lee JH, Chang JH. Clinical significance of EGFR mutation types in lung adenocarcinoma: $\mathrm{A}$ multi-centre Korean study. PLoS One 2020; 13;15(2):e0228925.

5. Chatterjee K, Ray A, Chattopadhyay B. Incidence and characteristics of Epidermal Growth Factor Receptor (EGFR) mutation in non-small-cell lung cancer (Adenocarcinoma histology): A report of 106 patients from Kolkata. IndianJ Cancer 2017;54(1):305-307.

6. Reinersman JM, Johnson ML, Riely GJ, Chitale DA, Nicastri AD, Soff GA et al. Frequency of EGFR and KRAS mutations in lung adenocarcinomas in African Americans.JThorac Oncol 201 1;6(1):28-31.

7. Song $Z$, Zheng Y,Wang X, Su H, Zhang Y,Song Y. ALK and ROS 1 rearrangements, coexistence and treatment in epidermal growth factor receptor-wild type lung adenocarcinoma: a multicenter study of 732 cases. J Thorac Dis 2017 ; 9(10):3919-3926

8. Zinsky R.Metaanalysis of ROS1-positive lung cancer cases.Eur RespirJ2016;48.

9. Prabhakar CN. Epidermal growth factor receptor in non-small cell lung cancer.Transl Lung Cancer Res 2015;4(2):110-8.

10. Tfayli A, Rafei H,Mina A, Khalil M,Fakhreddin N, Mahfouz R et al. Prevalence of EGFR and ALK Mutations in Lung Adenocarcinomas in the Levant Area - a Prospective Analysis. Asian Pac J Cancer Prev 2017; 1;18(1):107-114.

11. Matsumura M, Okudela K, Kojima Y, Umeda S, Tateishi Y, Sekine A et al. Histopathological Feature of EGFR-Mutated Lung Adenocarcinomas with Highly Malignant Potential - An Implication of Micropapillary Element. PLoS One 18;1 (11):e0166795, 2016.PMID: 27861549. DOI:10.1371/ journal.pone.0166795.

12. Ho HL, Kao HL, Yeh YC, Chou TY. The importance of EGFR mutation testing in squamous cell carcinoma or non-small cell carcinoma favor squamous cell carcinoma diagnosed from small lung biopsies. Diagn Pathol 2019; $21 ; 14(1): 59$.

13. Bergethon K, Shaw AT, Ou SH, Katayama R, Lovly CM, McDonald NT, Massion PP, Siwak-Tapp C, Gonzalez A, Fang R, Mark EJ, Batten JM, Chen H, Wilner KD, Kwak EL, Clark JW, Carbone DP, Ji H, Engelman JA, Mino-Kenudson M, Pao W, Iafrate AJ. ROS 1 rearrangements define a unique molecular class of lung cancers.JClin Oncol $2012 ; 10 ; 30(8): 863-70$. 